\title{
МЕРЕЖЕЦЕНТРИЧНА ВЗАЄМОДІЯ ЕКСПЕРТІВ У ФОРМАТІ НАРАТИВНОГО ДИСКУРСУ
}

\author{
О. О. Головін, О. Є. Стрижак, В. Ю. Величко \\ Центральний науково-дослідний інститут озброєння та військової техніки \\ Збройних Сил України
}

\begin{abstract}
Описуються методологічні основи та інструменти забезпечення інформаційно-аналітичної діяльності експертів у процесі використання та оброблення великих обсягів інорормаційних масивів. Визначаються базові фрункціональні категорії взаємодії з розподіленою інформацією, а саме: структуризація, класифікація, критеріалізація, синтез і оцінювання. Розглядаються теоретичні засади перетворення наративних описів документів у формат інтерактивних систем знань. Для цього визначається певний набір інструментів - таксономія, онтологія, індексація, пошук, міжконтекстне зв'язування, вибір, агрегація когнітивних фуункцій тощо. Однак первинним для цих процедур є фрормування таксономій, що відображають семантичну змістовність кожного документу. Застосування цих інструментів створює умови реалізації інфрормаційно-аналітичної діяльності експертів.
\end{abstract}

Ключові слова: експерт, онтологія, трансдисциплінарність, когнітивність, наратив, дискурс, завдання вибору, агрегатор.

\section{NETWORK-CENTRIC EXPERTS INTERACTION IN THE NARRATIVE DISCOURSE FORMAT}

\author{
O. O. Holovin, O. Ye. Stryzhak, V. Yu. Velychko \\ The Central Scientific Research Institute of Armament and Military Equipment \\ of the Armed Forces of Ukraine
}

Background. The methodological bases and tools for providing information-analytical activity of experts in the process of using and processing large volumes of information arrays are described. The aim of the work was to determine the methodological principles and tools that ensure the transformation of unstructured documents in the format of interactive knowledge bases.

Materials and methods. Results. The basic functional categories of interaction with the distributed information are defined, namely: structuring, classification, criterization, synthesis and estimation. Theoretical bases of transformation of narrative descriptions of documents into a format of interactive systems of knowledge are considered. To do this, a certain set of tools is defined - taxonomy, ontology, indexing, search, intertextual linking, selection, aggregation of cognitive functions, etc.

Conclusions. Transdisciplinarity realizes the reflexive and recursive properties of the whole information space. The primary is the formation of taxonomies that reflect the semantic content of each document. The use of these tools creates the conditions for the implementation of information and analytical activities of experts.

Key words: expert, ontology, transdisciplinarity, cognition, narrative, discourse, task of choice, aggregator.

\section{СЕТЕЦЕНТРИЧЕСКОЕ ВЗАЕМОДЕЙСТВИЕ ЭКСПЕРТОВ В ФОРМАТЕ НАРРАТИВНОГО ДИСКУРСА}

\author{
А. А. Головин, А. Е. Стрижак, В. Ю. Величко \\ Центральный научно-исследовательский институт вооружения и военной техники \\ Вооруженных Сил Украины
}

\begin{abstract}
Описываются методологические основы и инструменты обеспечения инорормационно-аналитической деятельности экспертов в процессе использования и обработки больших объемов инорормационных массивов. Определяются базовые фрункциональные категории взаимодействия с распределенной информацией, а именно: структурирование, классифиикация, критериализация, синтез и оценка. Рассматриваются теоретические основы преобразования нарративных описаний документов в формат интерактивных систем знаний. Для этого определяется определенный набор инструментов таксономия, онтология, индексация, поиск, межконтекстное связывание, выбор, агрегация когнитивных функций и тому подобное. Однако, первичным для этих процедур является фоормирование таксономий, отражающих семантическую содержательность каждого документа. Применение этих инструментов создает условия реализации информационноаналитической деятельности экспертов.
\end{abstract}

Ключевые слова: эксперт, онтология, трансдисциплинарность, когнитивность, нарратив, дискурс, задача выбора, агрегатор.

(с) О. О. Головін, О. Є. Стрижак, В. Ю. Величко 
Вступ. Довільна інформаційно-аналітична діяльність експертів, носить мережецентричний характер і реалізується на засадах трансдисциплінарної взаємодії усіх інформаційних ресурсів (IP) і процесів, що ії складають. Одним із головних факторів цих процесів $є$ наявність трансдисциплінарно пов 'язаних між собою процесів оброблення, зберігання, розповсюдження та використання великих обсягів інформації і знань у вигляді неструктурованих документів [1- 4]. Перетворення таких пасивних систем знань може бути реалізованим на основі застосування когнітивних процедур - структуризація аналіз/ виділення проблеми, синтез, вибір тощо. На їх основі реалізується взаємодія експертів і спеціалістів у форматі наративного дискурсу $[2,5,6]$ з мережевими інформаційними ресурсами. При цьому забезпечуються трансдисциплінарні перетворення всіх документів, що їх складають у формат інтерактивних баз знань [1, 2, 4, 7].

Введемо такі поняття:

1. Когнітивна система, когнітивна структура [1, $2,8,9]$ - система пізнання людини, що склалася в його мисленні, як результат розвитку його характеру, виховання, навчання, спостереження та роздумів про навколишній світ. Із точки зору інформаційних технологій це означає наявність сталих шаблонів (patterns) визначення цілей, алгоритмів прийняття рішень у відповідності до певного стану об’єктів аналізу з метою отримання достовірних результатів у майбутньому.

2. Наратив $[2,4,5,10]-$ універсальна модель встановлення зв'язків за змістом між текстами документів та іншими формами подання інформації, що розглядає процес їх зв’язування як форму подання змістовних зв'язків у вигляді графів.

3. Дискурс $[4,5]-$ міркування, доказ, що визначаються з точки зору інформаційних технологій, як певні алгоритми та програмні сервіси на їх основі.

4. Таксономія $[1,2,10,11]$ - структура, порядок, закономірність, що базуються на принципах і практичному застосуванні алгоритмів класифікації, систематизації складноорганізованих і пов'язаних за ієрархією об'єктів або сутностей.

Усі вказанні категорії мають складну структуру та функціональність. Але на їх засадах сьогодні ефективно реалізуються інформаційно-аналітичні середовища.

Мета дослідження: визначення методологічних принципів та інструментів, що забезпечують перетворення неструктурованих документів у формат інтерактивних баз знань.
Результати та їх обговорення. Трансдисциплінарні ознаки діяльності експертів в інформаційному середовищі. Як вже було відмічено, використання мережевих документів в інформаційно-аналітичній системі потребує їх перетворення в активну форму знань, що можна представити первинно як онтологічну систему $[1,2,4,12]$ у вигляді:

$$
O_{t}=\left\langle X, R, F, A, D, R_{S}\right\rangle .
$$

Пасивні системи знань фактично являють собою певні тексти, що відображаються у вигляді послідовного викладання концептів, стійко заданих умов їх існування, описів їх властивостей та функціональностей тощо.

Тобто існує можливість перетворення онтології (1) у деяку систему такого виду:

$$
\left.O_{n r}=X(K), p>\right\rangle,
$$

де $O_{n r}$ - документ із послідовно визначеними описами контекстів (описи) концептів , - відношення суворого порядку, що визначає умови існування концептів у тексті.

Тоді $O_{n r}$ у подальшому будемо розглядати як певний наратив, що визначається послідовним викладанням описів певних фактів, процесів та їх властивостей у суворо послідовному вигляді. Тобто, наратив — це виколота онтологія виду (2), що фактично є простим текстом, який пасивно відображає певну систему знань.

При розгляді систем виду (2) існує можливість встановлювати тільки міжконтекстні зв'язки суворого впорядкування, тобто утворювати кінцеві послідовності виду:

$$
<X_{i}\left(K_{j}\right) \mid i=\overrightarrow{1, n} ; j=\overrightarrow{1, m}>\text {. }
$$

Вираз (3) інтерпретує пасивну інтеграцію наративів виду (2), а для його перетворення в інтерактивну форму виду (1) треба визначити умови інтегрованої операціональності [3, 13-15], а саме: аналізу та структуризації (оброблення), синтезу (комунікації) та вибору (прийняття рішень) [1, 2, 16-20].

Слід зазначити, що операціональність довільного тексту $[10,11]$ виду (2) та (3) визначається такими гіпервластивостями: рефлексія $-R_{f}$ рекурсія $-R_{k}$ ' редукція $-R_{d}$. Ці гіпервластивості утворюють певну замкнуту множину , що забезпечуює зв’язування та динамічну зміну упорядкування контекстних описів наративу $[2,5,6]$. Вказані гіпервластивості мають трансдисциплінарний та інтерпретуючий характер $[1-3,14]$ :

$$
R 3=\left\{R_{f}, R_{k}, R_{d}\right\},
$$

де: рефлексія — реалізує категорії інтегрованості, системності і відсутності змістовних розривів 
y масиваx Big Data та забезпечує відстеження та модифікування власних структур і стійкості їх поведінки під час активації;

рекурсія - реалізує категорію повторюваності процесів, явищ і форм їх операціонального відображення під час їх активації в інформаційному просторі;

редукція - реалізує методологічний принцип, відповідно до якого складні явища можуть бути декомпозовані та повністю пояснені на основі законів, властивих більш простим процесам та об’єктам.

Виходячи з значених понять - онтологія, наратив, рефлексія, рекурсія, редукція визначимо категорію трансдисциплінарності, що характеризує процес інформаційно-аналітичної діяльності експертів. У вузькому сенсі під трансдисциплінарністю системи знань будуть розумітися умови застосування рефлексивно активної рекурсивної редукції $F_{R 3}$.
Це значить, що виколоту онтологію виду (2) можна розширити множиною $R 3$ і $R$ гіперфункцією їі інтерпретації $F_{R 3}$

$$
O_{n r}=<X(K), p>\rightarrow O_{n d}=<X(K), R 3, F_{R 3}>.
$$

Отже, через перетворення (5), шляхом підстановки множини гіпервластивостей $R 3$ та за рахунок функціонального розширення $F_{R 3}$ замість відношення суворого впорядкування $p$ отримано онтологічну систему $O_{n d}$, що забезпечує різні види зв'язків між концептами $X$ і контекстами $K$.

Правила формування таких зв'язків будуть описані нижче, а узагальнену схему перетворень мережевих документів в онтологічну систему наведено на рис. 1 .

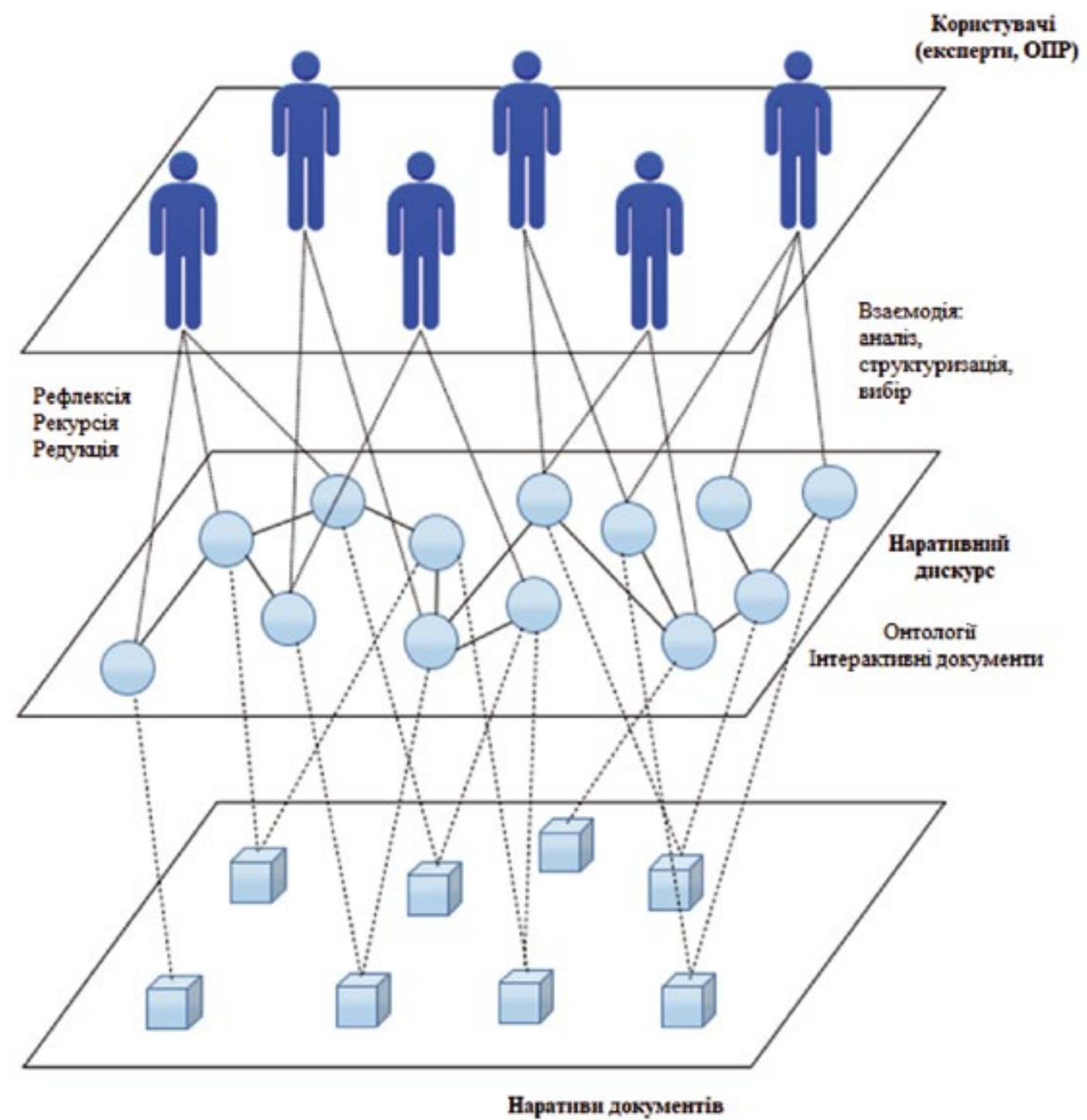

Рис. 1. Організація взаємодії з мережевими документами на трансдисциплінарних засадах 
Когнітивні засоби орієнтовані на оброблення інтегрованої інформації, що формується у процесах взаємодії з IP на основі міжконтекстних зв'язків.

Множинність цих міжконтекстних зв' язків доцільно представити у вигляді таксономій [2, 5, 6].

Тоді онтологічну систему виду $O_{n d}=<X(K), R 3, F_{R 3}>$. що складає праву частину виразу (5) можна представити у вигляді окремих випадків:

$$
\begin{aligned}
& O_{d}=<X(K), R_{f}, F_{R 3}>; \\
& O_{d}=<X(K), R_{k}, F_{R 3}>; \\
& O_{d}=<X(K), R_{d}, F_{R 3}>.
\end{aligned}
$$

Усі ці вирази представляють категорію дискурсу між документами, як когнітивно-коммунікативного акту, що одночасно реалізує на основі бінарного міжконтекстного зв'язку інтегрований опис обраних процесів та їхню інтепретацію як відображення та уявлення [1, 2, 7, 15]. Однією з властивостей дискурсу є можливість відображати зв'язаність двох і більше наративів.

Останнє дозволяє визначити наративний дискурс $[2,5,6]$ як взаємодію документів, що представлені у вигляді онтологічних систем на засадах вербально активної гіперфункції $F_{R 3}$, що реалізує їх систематизацію, а саме - аналіз, структуризацію, класифікацію, крітеріалізацію, синтез, оцінювання тощо.

Функція $F_{R 3} \in$ вербально-активною тоді й тільки тоді, коли онтологічна система, яку вона інтерпретує, включає всю множину $R 3$.
Тобто наративний дискурс множини мережевих документів представимо у вигляді правої частини виразу (5):

$$
O_{n d}=<X(K), R 3, F_{R 3}>\text {. }
$$

Таксономія, як система структурного аналізу наративу. Визначення наративу, дискурсу та наративного дискурсу дозволяє розглядати категорію єдиного інформаційного простору на засадах інтеграції трансдисциплінарних онтологій [1-6]. Проте, детальніший розгляд процесу взаємодії з мережевими інформаційними ресурсами потребує виділення категорії, для якої структурне представлення - унарна властивість [2, 16, 21]. Такою категорією являється таксономія [1, 2, 7, 10]. На її основі реалізується структурне відображення як окремого документу, так і досить великої за обсягом колекції документів.

Таксономія документів $(T)$ розглядається як певний результат застосування когнітивної процедури структуризації текстових масивів на основі системологічного представлення їхньої термінологічної системи в ієрархічному вигляді. Результатом застосування процедури таксономізації текстів $€$ представлення їхньої структури у вигляді графа без циклів [2, 12], кожна вершина якого містить відповідні контексти, зміст яких складають семантичні описи та характеристики відповідних термінів і словосполучень. Таксономія забезпечує виділення класифікаційних одиниць текстового масиву, що характеризують його семантику та призначення, а також відображає впорядкованість взаємодії між термінологічними конструкціями.

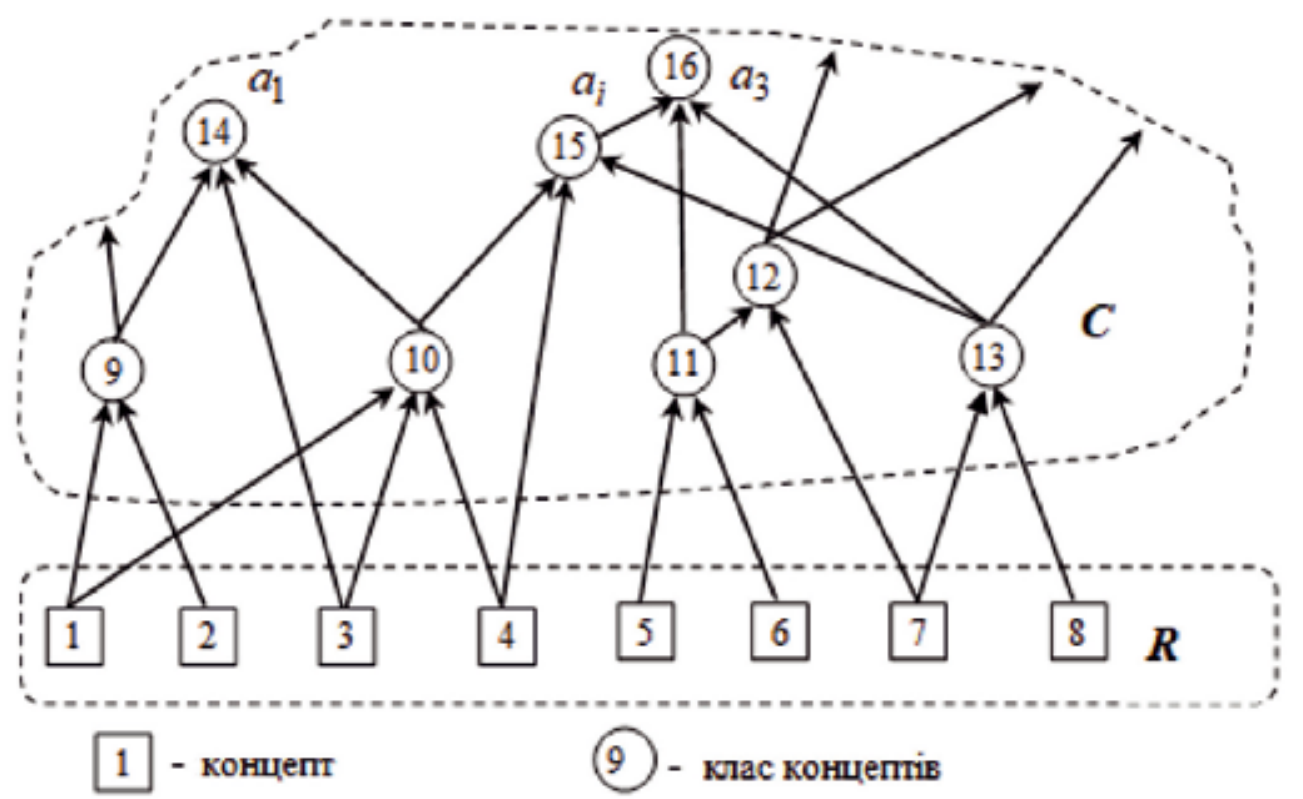

Рис. 2. Приклад семантичної мережі пірамідальної структури 
Зазначимо, що довільну таксономію, як множинне ієрархічне впорядкування термінів певної колекції документів, можна представити у вигляді зростаючої пірамідальної мережі, формат якої визначив V. Gladun $[12,18]$. Під пірамідальною мережеюч розуміється ациклічний орієнтований граф $\Psi=(X, E)$ з відсутніми вершинами, що мають одне ребро, котре заходить. $X=\left\{x_{i}|i=| \overline{1, n_{1}}\right\} \in$ множиною вершин мережі (концептів документу), де $x_{i}$ - довільна вершина мережі, $n_{1}$ - кількість вершин у мережі. Приклад семантичної мережі пірамідальної структури $[12,18]$ наведено на рис. 2.

Вершини, що не мають дуг, які заходять, утворюють термінальні концепти (термінали), інші вершини утворюють класи концептів (класи). Термінали відповідають окремим значенням ознак із описів об'єктів. Класи відповідають комбінаціям значень ознак, що ідентифікують об'єкт у цілому, або відповідним спільним частинам описів декількох об'єктів.

Множина вершин пірамідальної мережі - це множина X концептів пірамідальної мережі, де кожен концепт $x_{j}$ являє собою певну мовну лексичну одиницю:

$$
X_{i}=\text { поняття } \mid \text { слово } \mid \text { фраза. }
$$

Підграф пірамідальної мережі, що включає певну вершину $C \in X$ та всі вершини, з яких існує шлях до неї, називається пірамідою вершини С. Вершини, що входять до піраміди вершини $C$, утворюють ї̈ субмножину, яку позначимо як $X_{c}$. Вершини, що належать до $X_{c}$ та безпосередньо пов'язані з $C$ ребром будемо називати 0-субмножиною цієї вершини. Множина вершин, до яких входить вершина $C$, називається ії супермножиною, що позначимо як $\overline{X_{C}}$.

Зрозуміло, що $X_{C} \cup \overline{X_{C}}=\Psi_{C}$, де $\Psi_{C}$-пірамідальна мережа, яку утворено всіма концептами, що мають спільні ребра з вершиною $C$.

Такі таксономічні структури у вигляді зростаючої пірамідальної мережі, реалізують трансдисциплінарну категорізацію контекстів як системологічне, динамічне формування класів контекстних описів на основі утворення стійких бінарних сполучень між визначеними термінами, фразами та словоформами. Відображення семантичної зв’язності понять та їх контекстів, що відображають відповідні інформаційні ресурси, у вигляді пірамідальної мережі $\Psi є$ необхідною умовою формування множини таксономій, які спроможні відображати структурне різноманіття всього наративу текстових масивів, що утворюють зазначені ресурси. При цьому, пірамідальні мережі $\Psi$ унівалентні [21] таксономічним структурам T:

$$
\Psi \cong T
$$

Можемо стверджувати, що завжди існують непусті множини таксономій та пірамідальних мереж певного наративу, які також унівалентні між собою. Такі структурні відображення будемо називати наративним таксономічним різноманіттям (НТР):

$$
\left(\left\{T_{j} \mid j=\overline{1, m}\right\} \cong\left\{\Psi_{i} \mid i=\overline{1, n}\right\} \mid j \geq i, m>n\right) .
$$

Тобто довільна таксономія $T$ може бути утворена на основі певної кінцевої множини пірамідальних мереж виду - $\left\{\Psi_{i} \mid i=1, n\right\}$, що будемо називати таксономічним наративним різноманіттям (ТНР) та представляти у вигляді:

$$
T_{j} \cong \bigcup_{i-1}^{n} \Psi i
$$

Вирази (10-13) відображають той факт, що певна таксономія $T$ формується наборами концептів, які утворюють непусту множину пірамідальних мереж виду $\Psi=(X, E)$ деякого наративу.

Отже, множина $\left\{\Psi_{i} \mid i=\overline{1, n}\right\}$, що визначається множиною концептів $X €$ семантичним структурним відображенням наративного представлення інформаційних ресурсів. На основі цього можна стверджувати, що концепти $X$ НТР виду (13) визначають деяке термінополе (ТР) цього наративу, й це термінополе має відкритий характер. Тобто довільна таксономія $T$ може поповнюватися новітніми пірамідальними мережами $x_{k} \mid k>n$ ), що мають додаткові концепти.

Множина ребер $E$ пірамідальної мережі $\Psi$, виз начає тільки наявність бінарної зв' язності між ії концептами. Орієнтація цих ребер дозволяє групувати концепти за такими категоріями як термінальний клас, субмножина, супермножина, концент.

Термінальний концепт $x_{t}$ не має вхідних стрілок, тобто він не $\epsilon$ комутативним відносно бінарного ребра $e_{i}$ :

$$
\left(x_{t} \propto e_{i} \propto x_{i}\right) \neq\left(x_{i} \not e_{i} \propto x_{t}\right) .
$$

Клас $X_{l}^{K}$ визначає всі концепти, що належать певному категоріальному концепту $x_{i}$, який не $€$ термінальним:

$$
X_{l}^{K}=\left\{\mathrm{x}_{\mathrm{i}} \not \mathrm{e}_{\mathrm{i}} \propto X_{l}^{K}\right\} .
$$

Субмножина $X_{i}^{s b}$ визначає концепти, для яких вказаний (базовий) концепт $x_{i} \in$ категоріальним та не може бути термінальним:

$$
\begin{aligned}
X_{i}^{s b}=\{ & \left\langle<x_{i}^{j} e_{i}^{s b} e_{i+1}^{s b} x_{(i+1)}^{j} e_{(i+2)}^{s b} \ldots e_{(i+k-1)}^{s b} x_{(i+k)}^{j}>\right| \\
& >(i=\overline{1, m}),(k-\overline{i, m}),(j=\overline{1, l}),
\end{aligned}
$$

де $e_{i}^{s b}$ - ребро, яке позначено стрілкою та входить у базовий концепт $x_{i}$. 
Супермножина визначає концепти, що є категоріальними для вказаного (базового) концепту та можуть бути термінальними:

$$
\begin{aligned}
x_{i}^{\text {sup }}=\left\{<x_{i}^{j} e_{i}^{\text {sup }} e_{i+1}^{\text {sup }} x_{(i+1)}^{j} e_{(i+1)}^{\text {sup }} \ldots e_{(i+k-1)}^{\text {sup }} x_{(i+k)}^{j}>\right\} \mid & \mid(i=1, m),(k=i, m),(j=1, l),
\end{aligned}
$$

де $e_{i}^{\text {sup }}-$ ребро, що позначено стрілкою та виходить із базового концепту $x_{i}$.

Як можна бачити з виразів (16) та (17), ребра $e_{i}^{\text {sup }}$, $e_{i}^{s b}$ мають протилежну орієнтацію, що дозволяє визначити таке:

$e_{i}^{\text {sup }}+e_{i}^{s b}=e l$, де $e l-$ ейлеров підграф, для сильно зв'язаних концептів.

$e_{i}^{\text {sup }} \times e_{i}^{s b}=E L$, де $E L-$ множина ейлерових шляхів у пірамідальній мережі $\Psi_{i}$.

Концепт визначає всі категоріальні та термінальні концепти, що знаходяться від вказаного $x_{i}$ на певній відстані, значення якої є цілим числом й дорівнює кількості бінарних ребер, що їх з’єднує:

$$
\left(\sum_{1}^{n} e_{i} \mid e=1\right) X_{i}^{k c}=\left\{x_{i} \times \Pi_{1}^{l} \sum_{1}^{n} e_{i} x_{j}\right\},
$$

де 1 - відстань від концепту $x_{i}$ до концепту $x_{j}$, $n$ - кількість бінарних ребер від кожного концепту.

Виходячи з того, що пірамідальна мережа $\Psi_{i}$, за визначенням є орграфом без циклів, у неї відсутні ейлерови підграфи. Разом із тим, можливе штучне утворення непустої множини ейлерових графів і ейлерових шляхів на засадах застосування рефлексивно активної рекурсивної редукції $F_{R 3}$.

Визначена таксономічна функціональність реалізує процес категоризації контекстів усіх IP на основі системологічного, динамічного формування класів контекстних описів, що складають увесь наратив цих ресурсів.

Однак, для реалізації такого підходу необхідно забезпечити між термінами, словами, фразами та словоформами утворення стійких бінарних сполучень. Ці сполучення крім відображення таксономічних структур типу (10-17), повинні реалізовувати зв'язність між усіма системними компонентами таксономічних структур і забезпечувати їх упорядкування при проведенні аналітичних досліджень.

Слід зазначити, що властивості концептів за рахунок утворення бінарних зв'язків із гіпервластивостями множини $R 3(4)$, дозволяють визначити множину класів відношень між ними.

Утворення кожного такого класу реалізується наступним чином. Спочатку кожен такий клас іменується й далі наповнюється концептами документу, що мають бінарне відношення з іменем класу на основі утворення стійкого бінарного відношення між його властивістю та одним із гіпервідношень замкнутої множини $R 3$. Таке відношення має вигляд:

$<r_{k l}^{t}, R_{g},>\left|r_{k l}^{t} \in R_{k l}^{T}\right| R_{g} \in R 3, g \in R 3, g \in\{f, c, d\},(19)$

де $T$ - тип концепту, $t$ - властивість типу, $k l$ - спеціальний індекс, що є маркером атрибуту концепту.

Множинність наведеного бінарного відношення визначається тим, що воно зв'язує деякий набір концептів із ім'ям класу, який утворює даний набір концептів:

$$
\left\{x_{k l}^{t}<r_{k l}^{t}, R_{g}>X_{k l}^{T}\right\} .
$$

Класи концептів, також є елементами таксономії документу та можуть утворювати новітні класи:

$$
\left\{Y_{k l}^{t_{i}}<R_{k l}^{T^{t} j}, R_{g}>X_{k l}^{T_{n}}\right\} \cong X_{k l}^{T_{l}} .
$$

Представлення ім'я класу видом $X_{k l}^{T_{n}}$ свідчить про те, що цей клас утворено із концептів, які володіють $t_{n}-$ ю властивістю.

Уся сукупність класів утворює повну таксономічну систему документу над якою може бути визначена повна часткова упорядкованість. Тоді коренева вершина таксономії усього документу є нерухомою точкою множини [2, 16, 21], що включає всі концепти документу. Таксономічна система, що утворюється на основі вказаної множини концептів із нерухомою точкою також є повною.

Більш того, повна таксономічна система є структурованим об’єктом і може розглядатися з позицій теорії гомотопичної теорії типів [21]. Оскільки таксономія, як структурований об’єкт, утворюється на основі стійких бінарних сполучень між концептами документів, iï можна також розглядати як бінарне дерево [16, 21] гомотопичного типу та таким, що характеризується гіпервластивістю унівалентності [21]. Це дозволяє стверджувати, що таксономія довільного документу унівалентна всьому простору бінарних дерев, які можна утворити із його концептів.

$$
T \cong B_{D}
$$

За рахунок властивості унівалентності гіпервідношень забезпечується формування з класів концептів різних таксономічних структур.

Слід зазначити, що повна таксономічна система $T$ формується на основі виділення певної підмножини концептів $X$, які мають загальну характеристичну властивість. Така властивість може бути унарною для кожного концепту, проте при визначенні зазначеного класу, як складного концепту, така властивість дозволяє визначити над усіма концептами класу множинне бінарне відношення (бути елементом класу). 
При цьому, унарна властивість, що є загальною для множини концептів предметної області, може інтерпретуватися як ознака цих концептів або як критерій для вибору концептів даного класу.

Так, під час вибору концептів-кандидатів для формування певної категорії-класу (class), спочатку визначається властивість-ознака, на підставі якої дана категорія може бути представлена як складний концепт. При цьому, включення до категорії-класу конкретного простого концепту або поняття з менш складною структурою грунтується на унарній властивості-критерії, що характеризує його, та є загальною для всіх концептів цієї категорії-класу. Зазначена загальна властивість дозволяє визначити для даної категорії бінарне відношення «частина-ціле», що також задає часткову впорядкованість $[2,16]$ над усіма концептами сформованої категорії класів.

Отже, множина бінарного відношення часткової упорядкованості може бути задана на основі бінарного відношення «частина-ціле», що можна переписати у вигляді множинного відношення — «група об'єктів - об'єкт». Поняття «група об'єктів» визначає ім'я складного концепту-класу, що є таксономічною категорією для розглянутої предметної області. Вибір концептів для їх включення в таксономічну категорію за загальними семантичними властивостями можна розглядати як об'єднання одноелементних множин, де кожна така множина визначена конкретним концептом предметної області з обраною загальною для них властивістю-критерієм.

Конструктивність застосування процедури вибору [2, 16-20] проявляється можливістю точного визначення необхідного елемента для формування таксономії. Перевага критеріального вибору в даному випадку не залежить від методу ранжування. Таксономія задається концептами із загальною властивістю, над якими визначається множинне бінарне відношення часткової упорядкованості виду:

$$
x_{i}^{j} \tilde{p} x_{l}^{k} \stackrel{\alpha}{\longrightarrow} x_{i}^{j} p x_{l}^{k},
$$

в якому концепти мають властивості часткової впорядкованості - $\widetilde{p}$ та лінійної впорядкованості $-p[16]$.

Таксономія $T$ може бути визначена для будь-якого складного концепту, тобто за замовчуванням вона може бути утворена бінарним відношенням лінійної упорядкованості «частина-ціле». Відношення «частина-ціле» може бути розширено до множинного відношення «група об'єктів - об’єкт» і далі до «бути елементом класу» та/або «бути елементом категорії» $[7,10]$.
Гіпервідношення $G r$, задане над множинними бінарними відношеннями упорядкованості, що визначають таксономію, дозволяє сформувати предикативні вирази на основі іï концептів із заданим

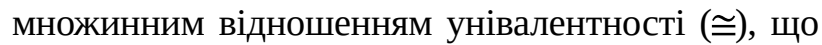
поглинає відношення часткової упорядкованості. Це поглинання одного гіпервідношення іншим має вигляд:

$$
\begin{aligned}
\left(x_{i}^{j} \tilde{p} x_{l}^{k} \stackrel{\alpha}{\longrightarrow} x_{i}^{j} p x_{l}^{k}\right) \vee(\cong)= & (\cong) \vee\left(x_{s}^{j} \tilde{p} x_{l}^{k}\right) \rightarrow \\
& \rightarrow(\cong) \vee x_{s}^{j} p x_{l}^{k} .
\end{aligned}
$$

Фактично вказане унівалентне поглинання визначає рівні еквівалентності таксономічних систем, що відображають документи, які мають спільні властивості. За результатами формування множини класів концептів таксономічної системи та за допомогою унівалентності отримуємо метатаксономію, концептами якої є задано множинне бінарне відношення «частина-ціле» $[2,10]$ :

$\operatorname{Pr}\left(x_{1}, \ldots x_{n}\right)=0 \Rightarrow$

$\Rightarrow \exists T \subseteq \breve{T}: \forall x \in X \exists Y \subseteq X: T=Y G r x$

де $Y$ - множина всіх можливих множин концептів $X$ таксономічної категорії $\breve{T}$, а $x_{i}-$ один із концептів цієї множини.

Отже, відношення унівалентності визначає взаємодію між концептами кожної таксономії, що виділена з різних класів концептів предметної області й, відповідно, дозволяє визначити нові види таксономічних систем.

Зазначений підхід, що визначається виразами (1-25) дозволяє реалізувати таксономічне представлення наративу цифрової колекції усієї сукупності мережевих документів.

Наративний дискурс як форма трансдисциплінарної взаємодії контекстів. Однією з властивостей дискурсу, як когнітивно-коммунікативного акту, $\epsilon$ можливість відображення зв'язності двох і більше наративів [2, 8, 9]. Відповідно, наративний дискурс визначає наявність вербально активних когнітивних процедур оброблення знань $[1,2,8,9]$, що забезпечують їхню систематизацію, а саме - аналіз, структуризацію, класифікацію, крітеріалізацію, синтез та оцінювання.

Тобто, можна визначити певну когнітивну процедуру багатоетапного послідовного перетворення первинної структури наративу тексту в онтологічний вигляд на основі виділення таксономічних систем виду $T$. Така процедура забезпечує автоматичне перетворення текстового наративу, що визначається упорядкованими на основі певних правил синтаксису 
$\Lambda$, які задаються над концептами $x_{i} \in X$ таксономією $T$, тезаурусом T і онтологією $\mathbb{O}$. Результатом застосування процедури $є$ виявлення концептів виду $x_{i}$, 3 яких складаються класи об'єктів предметної області (зокрема, їхні назви), виявлення первинних міжконтекстних зв’язків і таксономічне представлення семантики тексту.

Правила (5-9, 11-13, 20-25) визначають характер взаємодії текстів як систем знань у форматі наративного дискурсу. Так при значенні у виразі (20) параметру g=f, отримуємо множинність бінарних утворень між контекстами певних концептів із різних класів у такому вигляді:

$$
<r_{k l}^{t}, R_{f},>\left|r_{k l}^{t} \in R_{k l}^{T}\right| R_{f} \in R 3 .
$$

Ковзне значення властивості типу $\mathrm{t}$, реалізує утворення множини бінарних відношень між контекстами концептів із різних класів. Проте, кожен клас за рахунок наявності зв'язків між контекстами концептів може бути представленим у вигляді таксономії $T$. Отже, утворюється супермножина таксономій $\breve{T}$, між елементами якої встановлено множинне відношення рефлексії. А відповідно до виразу (17) така супермножина може об’єднувати категоріальні класи. Тоді у супермножині таксономій наративного дискурсу документів може бути штучно виділено множину ейлерових підграфів $E^{\text {sup* }}$. Більш того, відношення рефлексії може штучно утворювати непусту множину з ейлерових циклів, що включають у себе непусті класи концептів. Цей ейлерів підграф відображає наявність міжконтекстних зв'язків між різними концептами з різних класів. Отримуємо набір вербально активних когнітивних процедур оброблення знань, що й утворюють наративний дискурс.

3 метою позбавлення множинності типу «один концепт - група концептів» над супермножиною $\breve{T}$, задається гіпервластивість рекурсії, що забезпечує виділення $з$ неї лінійно упорядкованих ланцюгів концептів із одного та більше класів. Тобто, якщо рефлексія визначає таку гіллясту структуру множинності та концентричний вигляд наративного дискурсу, то рекурсія представляє його у вигляді певного ломаного відрізку.

Цей відрізок має вигляд правила (16) й утворюється елементами підмножини $\widehat{T}$, що суворо належить супермножині $\breve{T}: \widehat{T} \subset \breve{T}$.

Усі ці перетворення наративу тексту документів у наративний дискурс можна представити у вигляді системи правил [1, 2, 32].

Перетворення множини $X$ концептів пірамідальної мережі $\Psi$, що утворює супермножину таксономій
$\breve{T}$ у підмножину концептів $Y$ реалізується на основі унівалентності $\Psi$ супермножині таксономій $\breve{T}$.

$$
F_{R 3}: X \rightarrow Y \text {. }
$$

Перетворення (16) можна представити у рекурсивному вигляді:

$$
F_{R 3}(X)=\left\{\begin{array}{c}
F_{R 3}(X, \Psi, \breve{T}) \rightarrow \breve{T} \\
\left\{X_{i}^{s b}\right\} \\
\left\{X_{i}^{\text {sup }_{i}}\right\}
\end{array} .\right.
$$

3 урахуванням рекурсивного перетворення (17) можна побачити та шляхом реалізації відповідного гіпервідношення з множини фактично визначаємо які типи таксономічних структур будуть задіяні для взаємодії у форматі наративного дискурсу.

Індексна агрегація наративу семантично пов'язаних документів. Використання в інформаційноаналітичній діяльності мережевих документів у форматі наративного дискурсу визначає проблему їх контекстної агрегації. Відповідно до правил (10-13), (19-26) та перетвореннями виду (27-28) можна виділити всі множини міжконтекстних зв'язків. Але ця структура не є оптимальною для використання. Відповідно до визначення пирамидальної мережі $\Psi$, маємо графову структуру, що відображається у вигляді списків. Така структура не забезпечує оперативного відображення та використання необхідних контекстів, що визначає доцільність застосування інструментів прямої адресації. Останнє стає можливим за умови реалізації індексної агрегації як безпосередньо наративу всіх документів, так і елементів супермножини таксономій наративу $\breve{T}$.

Застосування гіпервластивостей множини $R 3=\left\{R_{f}, R_{k}, R_{d}\right\}$ на основі формування супермножини таксономій $\breve{T}$ та перетворень (27-28) дозволяє визначити функцію контекстної зв’ язності як композицію функції індексації та функції пошуку.

Функція контекстної зв'язки дозволяє встановлювати зв’язки між контекстами всіх концптів наративних описів мережевих документів, що визначають змістовну компоненту інформаційно-аналітичного середовища.

Функція індексації $Q_{I}$ має вигляд:

$$
Q_{I}(C)=\bigcup_{T \in C} \bigcup_{l \in L_{T}}\{<V(l), V(T)>\},
$$

де $C$ - множина наративних описів мережевих документів $N D, T$ - певна таксономія наративного документу $N D, L_{T}$ - набір концептів виду $x^{s b} \times x^{\text {sup }} \times \breve{T}$, 
що формує текстове представлення контекстів таксономії наративу документу $N D, V(l), V(T)-$ ідентифікатори лексеми, як певної кінцевої лінійно впорядкованої сукупності лексичних одиниць: $l=<x_{i} \mid$ поняття $\mid$ слово $\mid$ фраз $a>$ та таксономії $T$ наративу документу $N D$ відповідно.

Функція пошуку відповідних контекстів та лексічних одиниць, використовує результати застосування функції індексації.

$$
Q_{S}(l, \breve{T})=\{I \mid<\{V(l) \times X(T)\}>\},
$$

де $I$ - індекс, що являє собою результат роботи функції $Q_{l}$.

За допомогою функції пошуку можна формувати зв'язки між контекстами всіх лексичних одиниць множини мережевих наративних документів.

Тоді функція контекстної зв'язності матиме вигляд:

$$
Q_{C}(l)=\bigcup_{L_{T}}\left(Q_{s}(Q(C), \breve{T}),\right.
$$

де $C$ - множина наративів мережевих документів $N D$, що визначають змістовність інформаційного середовища, в рамках якого здійснюється зв'язування, $x$ - лексична одиниця виду (1), з якою здійснюється зв'язування, $L_{x}$ - текстове представлення контексту лексичної одиниці $x, l$ - певна лексема $l=x_{i} \neq x$.

Множина індексів $\{I\}$, що формується на основі застосування до множини $C$ функції індексації $Q_{I}$, формує індексну зону $\widetilde{I}$ усіх наративів мережевих документів ND:

$$
\widetilde{I}=\{\{I\} \times \breve{T}\} .
$$

На основі виразу (32) функцію контекстної зв'язності можно представити у вигляді:

$$
Q_{c}(l)=\widetilde{I} \times C \times \breve{T} \times R 3 .
$$

Отже, застосування функції контекстної зв'язності утворює умови з формування наративного дискурсу на основі семантико-лексичного та концептографічного оброблення всіх наративів мережевих документів $N D$.

Для дослідження використання терміну в рамках великого масиву інформаційних ресурсів, у тому числі й мережевих, на основі композиції функції контекстної зв'язності та перетворення рекурсивної редукції формується агрегат лексичних одиниць наративного дискурсу:

$$
\Theta=Q_{c}(l) \times F_{R 3}(X) .
$$

Агрегат наративного дискурсу фактично представляє набори контекстів лексичних одиниць, що зв’язані між собою різними відношеннями, включаючи й гіпервідношення множини $R 3$.

Онтологія завдань вибору, як основа взаємодії у форматі наративного дискурсу. В контексті взаємодії у форматі наративного дискурсу на основі агрегатного відображення лексичних одиниць наративу документів виду (34), виникає проблема щодо перевпорядковування станів їх відображення:

$$
\Theta=Q_{c}(l) \times \tilde{p} \times F_{R 3}(X) .
$$

Будемо розглядати взаємодію експертів у форматі наративного дискурсу шляхом представлення всього простору відображення контекстів на основі натуральних систем відповідно до $[1,2,16]$. Натуральна система $S N$, забезпечує відображення контекстів певного документу у процесі інтерактивної взаємодії з його змістом. Такий документ можна визначити як інтерактивний $[1,2]$ і представити за допомогою пари

$$
\langle O, S N\rangle,
$$

де $O$ - онтологія, що являє собою структуризоване представлення деякого документу та внашому випадку може бути представлена у такому вигляді:

$$
O=<X, R(\Psi, \Theta), F\left(\breve{T}, F_{R 3}(l)>.\right.
$$

Довільна $S N$, що побудована на основі $O$, забезпечує отримання певного результату при функціональних перетвореннях виду (27-33), які завжди визначають певні результати та утворюють непустий набір дій $F_{s e t}$

Умова дійсності $F_{s e t}$ відповідно до [16] буде виконуватися оскільки, у нашому випадку, завжди існують функції, що задані на множинах концептів документів, їх таксономій тощо та описують певні відображення та перетворення. До функцій, що належать $F_{s e t}$, будемо відносити всі перетворення виду (27-34).

Відповідно до виразів (20-37) завжди можна визначити певні альтернативні стани взаємодії у форматі наративного дискурсу $-A_{s \nu}$, що відображають деякі агрегати наративного дискурсу. Зрозуміло, що контексти значень таксономій і концептів, які визначають такий агрегат, певним чином впливають на вибір найбільш оптимального стану взаємодії.

Множина таких альтернатив виду $A_{s t}$ визначає категорію вибору як наявність певної функції $f$, що кожному агрегату лексичних одиниць наративного дискурсу ставить у відповідність непусте значення функції контекстної зв'язності $Q_{c}(l) Q_{c}(l)$ :

$$
\forall E[\varnothing \notin T \Rightarrow \exists f: T \rightarrow \bigcup T, \forall T \in \breve{T}(f(T) \in \breve{T}] .
$$


Аксиоматичне представлення завдання вибору у вигляді виразу (38) дозволяє визначити проблему перевпорядковування представлення вирішення практичних завдань на засадах контекстної зв'язності при взаємодії у форматі наративного дискурсу.

Представимо категорію завдання $[13,14,16]$ як певний стан натуральної системи з визначеною ціллю, що потребує вибору певної дії чи певного об’єкту при взаємодії у форматі наративного дискурсу:

$$
S N(f(X), G L),
$$

де $G L$ — мета, що реалізується виконанням певної дії $f(X) \subset F_{\text {set }}$.

Зробимо наступну підстановку для $f(X)$.

Відповідно до правил (1-14) існує функція перетворення множини концептів $X$ у супермножину таксономій $\breve{T}$, що також відноситься до набору дій $F_{s e t}$ :

$$
f: X \rightarrow \Psi \cong T) \Rightarrow f(T) \subset F_{\text {set }} .
$$

Більш того, застосування сукупності правил (15-28), (34) та (40) дозволяє визначити таке представлення завдання вибору через стан натуральної системи $S N$ :

$$
S N(f(X), G L) \rightarrow S N\left(F_{s e t}, G L(\Theta)\right) .
$$

У виразі (41) набір усіх дій $F_{s e t}$ визначає той факт, що всі функціональні перетворення об’єктів, які складають наратив цифрової колекції усіх мережевих документів, розглядається без урахування правил граматики та синтаксису, а параметр $G L(\Theta)$ демонструє необхідність визначення конкретного агрегату наративного дискурсу, у форматі якого реалізується взаємодія. Для цього розглянемо онтологію натуральної системи $O_{S N}$, що забезпечує виконання певних дій $F_{s e t}$ над об’єктами наративного дискурсу.

Формування онтології завдання вибору, що постійно виникає у наративному дискурсі, дозволяє визначити контур контекстної зв’язності взаємодії у його форматі. Всі правила, а саме (1-41), якщо їх проінтерпретувати до процесів взаємодії у рамках інформаційно-аналітичної діяльності, дозволяють визначити контекстну зв'язність взаємодії таким виразом:

$$
O_{S N}=<\Theta,(R(\breve{T}), R 3),\left(f(T), F_{\text {set }}\right)>.
$$

Подібне представлення онтології вибору у розумінні наративного дискурсу визначає необхідність розуміння смислової зв'язності контекстів цифрових документів і відображає агрегат наративного дискурсу. Зрозуміло, що у виборі беруть участь і такі гіпервідношення, як рефлексія, рекурсія та редукція. Відповідно до класичного визначення онтології як певної системи, до їі системних компонентів обов'язково повинен бути включений набір функцій, що операціонально спроможні інтерпретувати всі семантичні властивості та відношення, які визначають об’єКти онтології.

Висновки. 1. Сучасне інформаційно-аналітичне середовище формується на трансдисциплінарних засадах повномасштабного використання інформаційних ресурсів, що обробляються та використовуються під час вирішення профільними експертами складних прикладних завдань, які характеризуються складною міждисциплінарністю та створені за допомогою різних технологій і стандартів. Трансдисциплінарність реалізує рефлексивні та рекурсивні властивості всього інформаційного простору. Більш того вона забезпечує його структурну та змістовно контекстну зв'язність. При цьому системні компоненти інформаційно-аналітичної платформи реалізують взаємодію з експертами у форматі наративного дискурсу, що забезпечує інтегроване застосування використовуваних інформаційних ресурсів.

2. Наративний дискурс забезпечує досить структуроване та зв'язне відображення всіх мережевих документів на засадах трансдисциплінарного їх представлення. Основною його перевагою є забезпечення смислової зв’язності контекстів цифрових документів, що відображають агрегат наративного дискурсу. Також суттєвий вплив на формат наративного дискурсу має зв'язність концептів термінополя предмету взаємодії, які відображаються відповідними таксономічними структурами, а також посилюють взаємодію у форматі наративного дискурсу та його можливості з відображення таксономічних структур об’єктів взаємодії, що забезпечують можливості їхнього вибору.

3. В мережецентричному трансдисциплінарному онтологічному середовищі на засадах агрегату наративного дискурсу онтології завдань вибору, що послідовно реалізують системологічну підтримку та документо-орієнтовану взаємодію у форматі наративного дискурсу, реалізується використання кожного контексту операціонального простору інформаційноаналітичної діяльності експертів у процесі прийняття рішень. 


\section{Література.}

1. Model of Transdisciplinary Representation of GEOspatial Information / Stryzhak O., Prykhodniuk V., Podlipaiev V. / Ilchenko M., Uryvsky L., Globa L. (eds) // Advances in Information and Communication Technologies. UKRMICO 2018. Lecture Notes in Electrical Engineering. - Springer, Cham, 2019. — Vol. 560.

2. Стрижак О. Є. Таксономічні засади наративного дискурсу / О. Є. Стрижак // Медична інформатика та інженерія. — 2020. — № 2. — С. 137-147.

3. Nicolescu B. Transdisciplinarity - Theory and Practice / B. Nicolescu. - Cresskill, NJ, USA : Hampton Press, 2008. - 320 p.

4. Palagin A. Transdisciplinarity, computer science and development of modern civilization / A. Palagin // Bulletin of the National Academy of Sciences of Ukraine. - 2014. — No. 7. - P. 25-33.

5. Elson D. K. Modeling Narrative Discourse / K. D. Elson . — New York City : Columbia University, 2012. — 383 p.

6. Riedl M. O. Interactive narrative: An intelligent systems approach / M.O. Riedl, Bulitko V. // AI Magazine. 2013. — Vol. 34 (1). — P. 67-77.

7. Широков В. А. Язык. Информация. Система : Трансдисциплинарность в лингвистике / В. А. Широков. - K., 2017. - 280 c.

8. Konar A. Cognitive Engineering: A Distributed Approach to Machine Intelligence / A. Konar // Series: Advanced Information and Knowledge Processing :Springer, Cham, 2005. - 354 p.

9. The Oxford Handbook of Cognitive Engineering / Edited by J. D. Lee and A. Kirlik. — 2013. - Peжим доступу: https://www.oxfordhandbooks.com/ view/10.1093/oxfordhb/9780199757183.001.0001/ oxfordhb-9780199757183.

10. Шаталкин А. И. Таксономия. Основания, принципы и правила / А. И. Шаталкин. - М. : Товарищество научных изданий КMK, 2012. - 600 с.

11. Mayer-Schönberger V. Big Data: A Revolution That Will Transform How We Live, Work, and Think / V. MayerSchönberger, K. Cukier. — Boston, MA : Houghton Mifflin Harcourt, 2013. - 252 p.

12. Gladun V. Processes of formation of new knowledge / V. Gladun. — Sophia : SD «Teacher 6», 1994. — 192 p.

13. Фридман Л. М. Основы проблемологии. Серия: Проблемология. / Л. М. Фридман. - М: Синтег, 2001. -228 c.

14. Piaget J. The Psychology of Intelligence / J. Piaget. London: Routledge and Kegan Paul, 1951.

15. Вайсфельд М. Объектно-ориентированное мышление / М. Вайсфельд. - СПб.: Питер, 2004. - 304 с.

16. Malyshevsky A. Qualitative models in the theory of complex systems / A. Malyshevsky. - Moscow : Fizmatlit, 1998. - 528 p.

17. Gorborukov V. Use of ontologies in decision-support systems / Gorborukov V., Stryzhak O., Franchuk O.
// Mathematical modeling in economics: collection of scientific works: S.O. Dovgy (head ed.) [And others]: NAS of Ukraine, Institute of Telecommunications and Global Information Space, Institute of Economics and Forecasting, Institute of Cybernetics named after Glushkov. - Kyiv, 2013. - Р. 33-39.

18. Структуризация и анализ данных в растущих пирамидальных сетях / В. П. Гладун, Н. Д. Ващенко, В. Ю. Величко, Ю. Г. Ткаченко // Системні дослідження та інформаційні технології - 2004. — № 1. C. 82-92.

19. Saaty T. The Analytic Hierarchy Process: Planning, Priority Setting, Resource Allocation / T. Saaty - RWS Publications, 1990. - 287 p.

20. Горборуков В. В. Технологічні засоби онтологічного супроводу розв'язання задач ранжування [Текст]: автореф. дис. на здобуття наук. ступеня д-ра техн. наук : спец. 05.13.06 «Інформаційні технології» / Вячеслав Вікторович Горборуков, НАН України. Ін-т телекомунікацій і глоб. інформаційного простору. Київ, 2018. - 20 с.

21. Voevodsky V. Univalent Foundations of Mathematics / V. Voevodsky // Proceedings of Logic, Language, Information and Computation WoLLIC 2011. Lecture Notes in Computer Science. - Berlin, Heidelber : Springer, 2011. - Vol. 664. 


\section{References.}

1. Stryzhak, O., Prykhodniuk, V., Podlipaiev, V. (2018). Model of Transdisciplinary Representation of GEOspatial Information. Advances in Information and Communication Technologies. UKRMICO 2018. Lecture Notes in Electrical Engineering. Springer, Cham, Vol. 560.

2. Stryzhak, O. Ye. (2020). Taxonomic principles of narrative discourse. Medical Informatics and Engineering, 2, 137-147. [in Ukrainian].

3. Nicolescu, B. (2008). Transdisciplinarity - Theory and Practice. Cresskill, NJ, USA : Hampton Press.

4. Palagin, A. (2014). Transdisciplinarity, computer science and development of modern civilization. Bulletin of the National Academy of Sciences of Ukraine, 7, 25-33. [in Russian].

5. Elson, D. K. (2012). Modeling Narrative Discourse. New York City : Columbia University.

6. Riedl, M. O., Bulitko, V. (2013). Interactive narrative: An intelligent systems approach. AI Magazine, 34 (1), 67-77.

7. Shyrokov, V. A. (2017). Language. Information. System: Transdisciplinarity in linguistics. Kyiv. [in Russian].

8. Konar, A. (2005). Cognitive Engineering: A Distributed Approach to Machine Intelligence. Series: Advanced Information and Knowledge Processing. Springer, Cham.

9. The Oxford Handbook of Cognitive Engineering. Edited by J. D. Lee and A. Kirlik. 2013. URL: https:// www.oxfordhandbooks.com/view/10.1093/oxfordhb/ 9780199757183.001.0001/oxfordhb-9780199757183.

10. Shatalkin, A. I. (2012). Taxonomy. Grounds, principles and rules. Moscow: Tovarishhestvo nauchnyh izdanij KMK. [in Russian].

11. Mayer-Schönberger, V., Cukier, K. (2013). Big Data: A Revolution That Will Transform How We Live, Work, and Think. Boston, MA : Houghton Mifflin Harcourt.

12. Gladun, V. (1994). Processes of formation of new knowledge. Sophia : SD «Teacher 6».

13. Fridman, L. M. (2001). Fundamentals of problemology. Series: Problemology. Moscow : Sinteg. [in Russian].

14. Piaget J. (1951). The Psychology of Intelligence. London: Routledge and Kegan Paul.

15. Vaisfeld, M. (2004). Object oriented thinking. Saint Petersburg : Piter. [in Russian].

16. Malyshevsky, A. (1998). Qualitative models in the theory of complex. Moscow : Fizmatlit. [in Russian].

17. Gorborukov, V., Stryzhak, O., Franchuk, O. (2013). Use of ontologies in decision-support systems. Mathematical modeling in economics: collection of scientific works. Kyiv. NAS of Ukraine, Institute of Telecommunications and Global Information Space, Institute of Economics and Forecasting, Institute of Cybernetics named after Glushkov, 33-39.
18. Hladun, V. P., Vaschenko, N. D., Velychko, V. Yu., Tkachenko, Yu. H. (2004). Structuring and Analyzing Data in Growing Pyramid Networks. Systemni doslidzhennia ta informatsijni tekhnolohii, 1, 82-92. [in Russian].

19. Saaty, T. (1990). The Analytic Hierarchy Process: Planning, Priority Setting, Resource Allocation. RWS Publications.

20. Horborukov, V. V. (2018). Technological support of the ontological superconduct for the connection of ranking tasks. Extended abstract of candidates thesis. Kyiv. Institute of Telecommunications and Global Information Space. [in Ukrainian].

21. Voevodsky, V. (2011). Univalent Foundations of Mathematics. Proceedings of Logic, Language, Information and Computation WoLLIC 2011. Lecture Notes in Computer Science. Berlin, Heidelber, Springer, 664. 